\title{
SAFETY ASSESSMENT OF THE LOW AND INTERMEDIATE LEVEL RADIOACTIVE WASTE NEAR-SURFACE REPOSITORY FOR STABATIŠKE SITE (LITHUANIA) *
}

\author{
V. Jakimavičiūtè-Maselienè ${ }^{\mathrm{a}, \mathrm{b}, \mathrm{c}}$, J. Mažeika $^{\mathrm{b}}$, and D. Baltrūnas ${ }^{\mathrm{a}}$

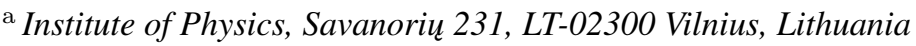 \\ E-mail: jakimaviciute@geo.lt \\ ${ }^{\mathrm{b}}$ Institute of Geology and Geography, T. Ševčenkos 13, LT-03223 Vilnius, Lithuania \\ ${ }^{c}$ Vilnius Gediminas Technical University, Saulètekio 11, LT-10223 Vilnius, Lithuania
}

Received 22 June 2007; revised 23 October 2007; accepted 21 November 2007

\begin{abstract}
A computer code FEFLOW 5.0 was applied for simulating transport of the most mobile radionuclides $\left({ }^{3} \mathrm{H},{ }^{14} \mathrm{C}\right.$, and $\left.{ }^{129} \mathrm{I}\right)$ with groundwater from the designed low and intermediate level radioactive waste near-surface repository at Stabatiške site. An analysis of the variability of the model parameters of hydrogeological system such as dispersivity, hydraulic conductivity, porosity, and radionuclide solid / liquid distribution coefficient $\left(\mathrm{K}_{d}\right)$ has been made. The obtained results show that the activity concentration of the most mobile radionuclides in aquifer will remain low for a long time after the repository closure and the conservatively predicted maximal annual effective dose $\left(8.9 \cdot 10^{-3} \mathrm{mSv} / \mathrm{y}\right)$ to the inhabitant will be much lower than the dose constraint $(0.2 \mathrm{mSv} / \mathrm{y})$.
\end{abstract}

Keywords: low and intermediate level radioactive waste, repository, groundwater, ${ }^{3} \mathrm{H},{ }^{14} \mathrm{C},{ }^{129} \mathrm{I}$, spreading, modelling, FEFLOW 5.0 code

PACS: 07.05.Tp, 28.41.Kw, 89.60.Ec

\section{Introduction}

About $100000 \mathrm{~m}^{3}$ of solid conditioned low and intermediate level waste (LILW), generated during operation and decommissioning of the Ignalina nuclear power plant (INPP), is to be disposed in a near-surface repository (NSR) - a "hill"-type repository with reinforced concrete vaults and with engineered and natural barriers $[1,2]$. The northeastern Lithuania and the environment of the INPP in particular were recognized as the areas most suitable for a near-surface repository [3]. It is essential to evaluate the risk and possible impact of the new nuclear object posed to the environment and population, therefore in this study using the computer code FEFLOW 5.0, the radionuclide transport with groundwater in environs of one preliminary investigated candidate site - Stabatiške site - was investigated in order to predict a possible range of key radionuclide spatial distribution and doses (Fig. 1).

The main attention is paid to the evaluation of ranges of parameters mostly influencing the assessment re-

\footnotetext{
* The report presented at the 37th Lithuanian National Physics Conference, 11-13 June 2007, Vilnius, Lithuania.
}

sults. The main parameters of the hydrogeological system were the following: porosity, hydraulic conductivity, dispersivity, and the radionuclide solid / liquid distribution coefficient $\left(K_{\mathrm{d}}\right)$.

\section{Materials}

\subsection{Waste and repository}

Both operational and decommissioning waste will be disposed of at the proposed NSR. The streams of the waste, which will be disposed of at the NSR, consist of spent ion-exchange resins, perlite and sludge (sediments), combustible solid waste, and non-combustible solid waste. Data on the expected waste inventory, forms, and amounts are extracted from the Ignalina NPP documents and the Final Decommissioning Plan for the Ignalina NPP Units 1 and 2 [1]. Aproximately 20 parent radionuclides will be present in the cemented waste matrix of the engineered barriers. The main activity forming radionuclides of inventory are the following: ${ }^{137} \mathrm{Cs}$ makes $41 \%$ of the total activity, ${ }^{60} \mathrm{Co}$ 


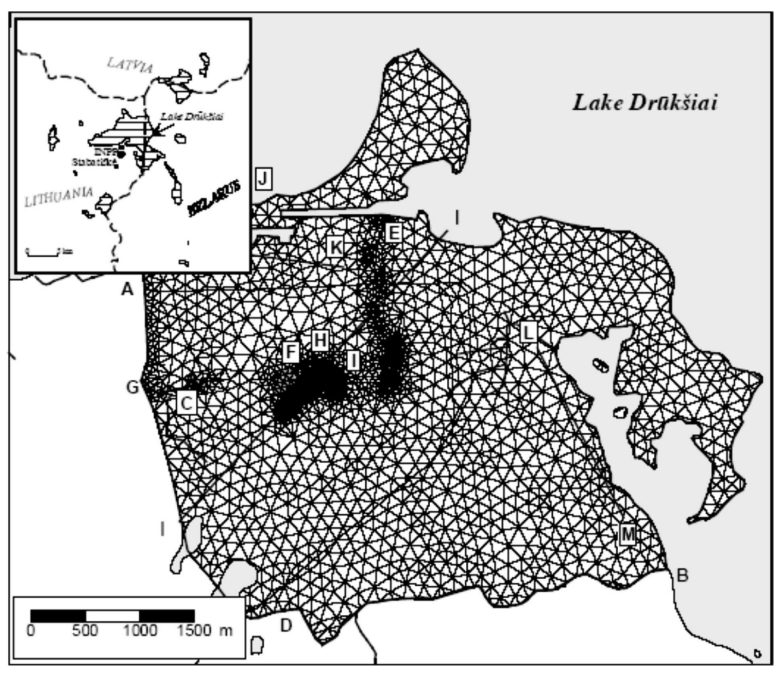

Fig. 1. Study area location, finite-element grid, and limits of model domain (Tables 1,2), and line of hydrogeological cross-section (Fig. 2).

$34 \%,{ }^{14} \mathrm{C} 12 \%$, etc. The $\alpha$ emitters comprise less than $0.008 \%$ of the total inventory.

A new waste management facility is under commissioning at the INPP site, where sediments and spent resin mixed with perlite will be immobilized with concrete in 200-liter drums, and these will then be placed into reinforced concrete storage containers.

The engineered barriers of the repository consist of concrete cells surrounded by clay-based material of low permeability with about the same isolating capacity in all directions. The clay materials must be effectively compacted so that required hydraulic conductivity could be reached. Such material exists in Lithuania and it has been investigated and tested [2]. The Lithuanian Triassic clay turned out to be sufficiently rich in smectites and was proposed as the main candidate for sealing of the repository. When the concrete vaults are filled, the repository cover will be constructed. The surface of the mound will be planted with grass. All details of the reference design of the near-surface repository are described in the Final Report [1].

\subsection{Hydrogeological setting}

Quaternary deposits of glacial origin (60-200 m thick) occur in the INPP region and are underlain by pre-Quaternary (Devonian, Silurian / Ordovician, Cambrian) and upper Proterozoic rocks. Alluvial, lacustrine, and bog deposits formed during the post-glacial period.

Local hydrogeological conditions of Stabatiškè site were characterized in detail referring to numerous studies and are schematically shown in Fig. 2.
At the surface, down to 4-12 m, till body (sandy loam and clayey loam) of low permeability lies (gIII bl+gr). A layer of peat (averaged thickness $2.7 \mathrm{~m}$ ) locally overlies till deposits. A thin $(0.5-1.5 \mathrm{~m})$ layer of glaciofluvial sand lies at the surface in many places of Stabatiške site as well. Groundwater (perched) accumulates in it only seasonally. This layer as a whole is drained by local boggy depressions. The first continuous semi-confined aquifer is overlain by the 5$9 \mathrm{~m}$ thick layer of till deposits (sandy loam and clayey loam). The aquifer itself is some 20-25 m thick and is composed of mixed grain sand. Groundwater is at a depth of 5-10 m (at altitude of 149.99-147.04 m above sea level, a.s.l.; the long-term water level in Lake Drūkšiai is $141.6 \mathrm{~m}$ a.s.l.). The aquifer has little or no connection with the boggy local depressions; it is drained to a larger extent by Lake Drūkšiai.

The hydraulic conductivity of the aquifer, depending on the grain size distribution of sand material, ranges from $5.3 \cdot 10^{-5}$ to $3.1 \cdot 10^{-4} \mathrm{~m} / \mathrm{s}$, and the hydraulic gradient is $0.009-0.01$. A hydraulic head around the site ranges from 147 to $154 \mathrm{~m}$ a.s.l. Hydraulic conductivity of low permeable layers ranges from $3.5 \cdot 10^{-9}$ to $1.5 \cdot 10^{-7} \mathrm{~m} / \mathrm{s}$. A confined low permeable layer from below (gIII md) occurs at altitude of $124 \mathrm{~m}$ a.s.l. and represents continuous aquitard.

\section{Methods}

The AMBER 4.5 code representing the compartment analysis tool was used to assess the radionuclide transport in the repository and to estimate the initial activity concentration of radionuclides in porewater of the cemented waste matrix [3]. Rather high level of conservatism was assumed: only a 50-year institutional control period was assumed, the saturation-percolation time through the repository was not taken into account, and the radionuclide leaching dynamics from the waste matrix was not modelled. The analysis of transfer of 20 radionuclides in the repository barriers showed that only ${ }^{14} \mathrm{C},{ }^{59} \mathrm{Ni},{ }^{94} \mathrm{Nb},{ }^{99} \mathrm{Tc}$, and ${ }^{129}$ I would reach the environment with groundwater, containing radionuclides, the activity values of which are insignificant. However, only two radionuclides $\left({ }^{14} \mathrm{C}\right.$ and $\left.{ }^{129} \mathrm{I}\right)$ were considered in further analysis, as well as ${ }^{3} \mathrm{H}$, since the latter is predicted to be fast transferred through engineered barriers although it has low activities (Fig. 3).

For consequent analysis of radionuclide transport with groundwater, all transport mechanisms were analysed using the computer code FEFLOW 5.0 [4]. The 


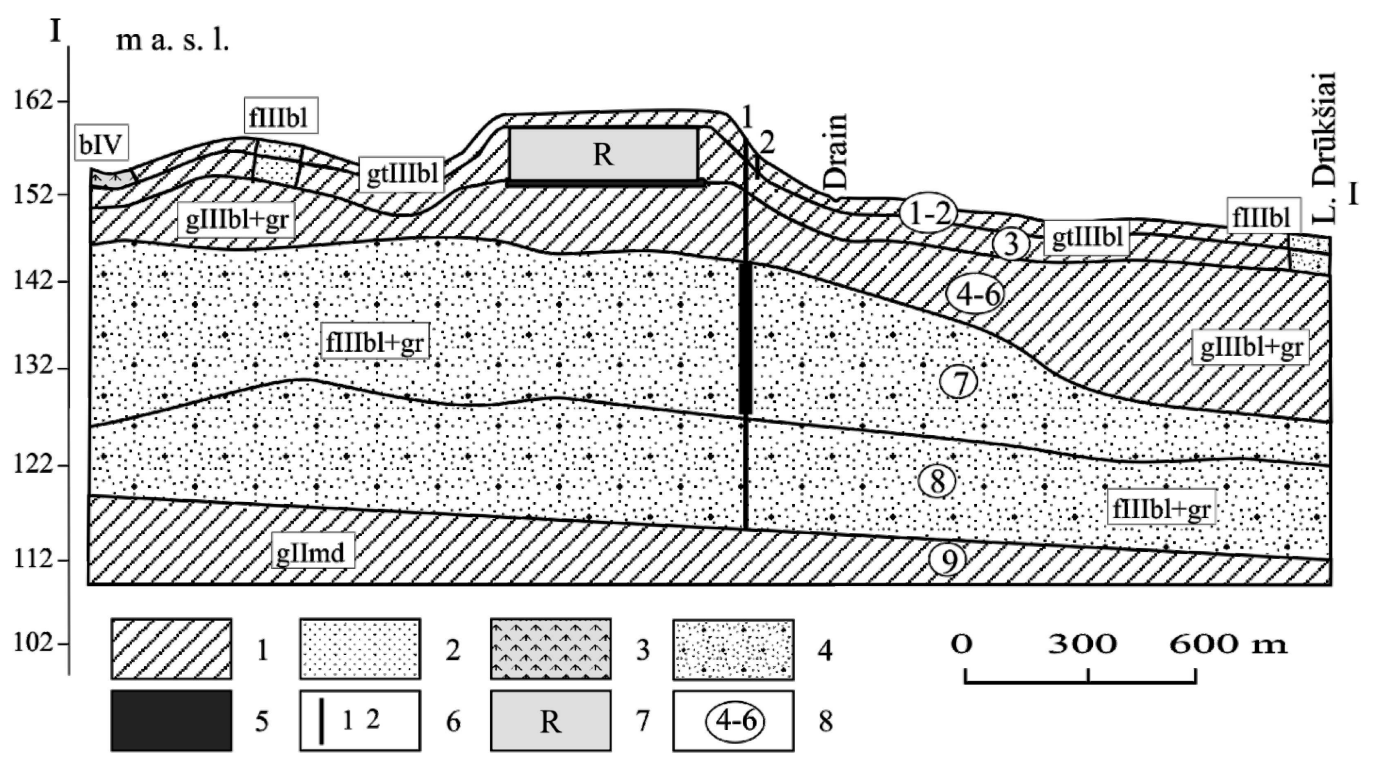

Fig. 2. Hydrogeological cross-section along line I-I (Fig. 1) of Stabatiškè site adjusted to the layers of flow and transport model: 1 till deposits (sandy and clayey loam), 2 fine-grained sand, 3 peat, 4 mixed grain sand, 5 gravel, 6 simulated pumping wells ( 1 screening semiconfined groundwater, 2 screening perched groundwater), 7 repository, 8 number of modelling layers.

Table 1. Features of the numerical model for the Stabatiškè site.

\begin{tabular}{|c|c|c|c|}
\hline Features & Explanation & Features & Explanation \\
\hline Problem class & Combined flow and mass transport model & Vertical exaggeration & $1: 1$ \\
\hline Time class & $\begin{array}{l}\text { Transient (unsteady) flow, transient } \\
\text { (unsteady) mass transport }\end{array}$ & Problem measure & $6973.28 \mathrm{~m}$ \\
\hline Time stepping scheme & $\begin{array}{l}\text { Adams-Bashforth / Trapezoid rule (AM / TR) } \\
\text { predictor-corrector }\end{array}$ & Number of layers & 9 \\
\hline Upwinding & $\begin{array}{l}\text { No upwinding for }{ }^{3} \mathrm{H} \text {, shock capturing } \\
\text { for }{ }^{14} \mathrm{C} \text { and }{ }^{129} \mathrm{I}\end{array}$ & Number of slices & 10 \\
\hline Number of time steps & Automatic & Type & Saturated \\
\hline Length of time step & Automatic & Dimension & Three-dimensional \\
\hline Error tolerance & $\begin{array}{l}1 \cdot 10^{-3} \text { applied to Euclidian } \mathrm{L}_{2} \text { integral } \\
\text { (RMS) norm }\end{array}$ & Element type & 6-noded triangular prism \\
\hline $\begin{array}{l}\text { Maximum number of iterations } \\
\text { per time step }\end{array}$ & 12 & Mesh elements & 54153 \\
\hline Adaptive mesh error & $1 \cdot 10^{-2}$ & Mesh nodes & 31050 \\
\hline A posteriori error estimator & Onate-Bugeda algorithm & Mesh optimization & Not done \\
\hline Velocity approximation & $\begin{array}{l}\text { Improved consistent velocity approximation } \\
\text { (by Frolkovic-Knabner algorithm) applied to } \\
\text { linear elements with local smoothing }\end{array}$ & Aquifers & $\begin{array}{l}\text { Unconfined (phreatic); another } \\
\text { aquifer is fixed (rigid slice, } \\
\text { stationary at stratigraphic unit) }\end{array}$ \\
\hline Form of transport equation & Convective & Projection & None (3D with free surface) \\
\hline Solver & Iterative equation solver & Adsorption law & Henry isotherm \\
\hline
\end{tabular}

Table 2. Boundary conditions of flow transport after model calibration (see Fig. 1).

\begin{tabular}{llll}
\hline Section or point (slice) & \multicolumn{1}{c}{ Type } & \multicolumn{1}{c}{ Value } & \multicolumn{1}{c}{ Comments } \\
\hline A-B (1-2) & Dirichlet (1st kind) & $h=141.6 \mathrm{~m}$ a.s.l. & Pervious boundary (outflow) \\
A-B (3-10) & Dirichlet (1st kind) & $h=142 \mathrm{~m}$ a.s.l. & Pervious boundary (outflow) \\
A-C (1-2) & Dirichlet (1st kind) & $h=141.6-150.8 \mathrm{~m}$ a.s.l. & Pervious boundary (outflow) \\
B-D (1-2) & Dirichlet (1st kind) & $h=141.6-152.8 \mathrm{~m}$ a.s.l. & Pervious boundary (outflow) \\
E-F (1-2) & Dirichlet (1st kind) & $h=141.6-150.8 \mathrm{~m}$ a.s.l. & Pervious boundary (outflow) \\
G-D (1-4) & Dirichlet (1st kind) & $h=151.5 \mathrm{~m}$ a.s.l. & Pervious boundary (inflow) \\
G-D (5-10) & Dirichlet (1st kind) & $h=151.5 \mathrm{~m}$ a.s.l. & Pervious boundary (inflow) \\
J-K (7-10) & Dirichlet (1st kind) & $h=147.5 \mathrm{~m}$ a.s.l. & Pervious boundary (outflow) \\
L-M (7-10) & Dirichlet (1st kind) & $h=145.5 \mathrm{~m}$ a.s.l. & Pervious boundary (outflow) \\
H (6) & (4th kind) & $Q_{\rho}^{w}=30 \mathrm{~m}^{3} / \mathrm{d}$ & Pumping rate of single well \\
I (3) & (4th kind) & $Q_{\rho}^{w}=0.1 \mathrm{~m}^{3} / \mathrm{d}$ & Pumping rate of single well \\
\hline
\end{tabular}




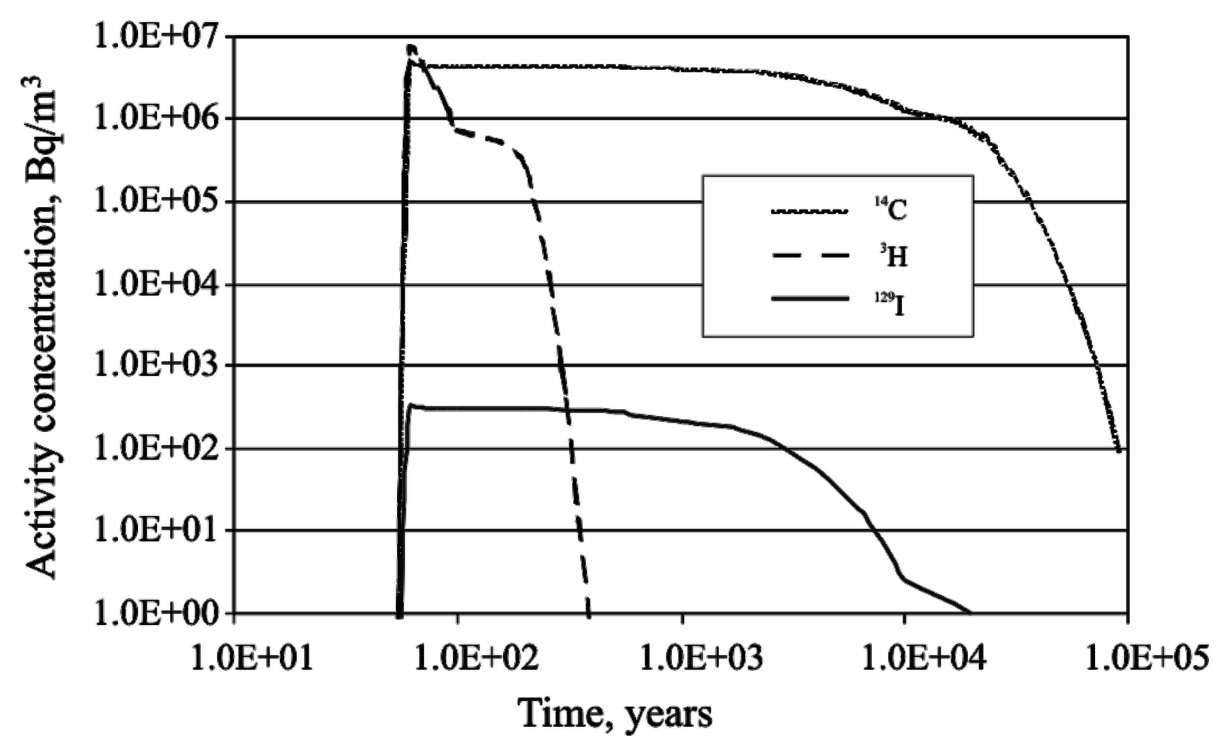

Fig. 3. Activity concentrations of simulated radionuclides $\left({ }^{3} \mathrm{H},{ }^{14} \mathrm{C},{ }^{129} \mathrm{I}\right)$ in the pore water of cemented waste taking into account $100 \%$ instant release of radionuclides to pore water 50 years after the repository closure. Inventory per volume unit: $1.0 \cdot 10^{8} \mathrm{~Bq} / \mathrm{m}^{3}$ of ${ }^{3} \mathrm{H}$, $4.7 \cdot 10^{9} \mathrm{~Bq} / \mathrm{m}^{3}$ of ${ }^{14} \mathrm{C}, 5.2 \cdot 10^{3} \mathrm{~Bq} / \mathrm{m}^{3}$ of ${ }^{129} \mathrm{I}(0.3,12$, and $0.00001 \%$ of total inventory, respectively).

Table 3. Boundary conditions of mass transport after model calibration.

\begin{tabular}{cll}
\hline Point (layer) & \multicolumn{1}{c}{ Type } & \multicolumn{1}{c}{ Comment } \\
\hline${ }^{3} \mathrm{H},{ }^{14} \mathrm{C},{ }^{129} \mathrm{I}(3)$ Polygon & Dirichlet (1st kind); time-varying function \\
& $C\left(x_{i}, t\right)=C_{1}^{R}(t)$ & $\begin{array}{l}\text { Time-varying activity concentration }\left(\mathrm{Bq} / \mathrm{m}^{3}\right) \\
\text { in pore water of saturated cemented waste }\end{array}$ \\
\hline
\end{tabular}

computer code FEFLOW 5.0 is based on the physical conservation principles for mass, chemical species, linear momentum, and energy in a transient and threedimensional numerical analysis.

For three-dimensional (3D) and two-dimensional (2D) (vertical and axisymmetric, respectively) processes, the used model general equations are as follows $(i, j=1,2,3)$ :

$$
\left\{\begin{array}{c}
S_{0} \frac{\partial h}{\partial t}+\frac{\partial q_{i}^{f}}{\partial x_{j}}=Q_{\rho}+Q_{E B}(C, T), \\
q_{i}^{f}=-K_{i j} f_{\mu}\left(\frac{\partial h}{\partial x_{j}}+\frac{\rho^{f}-\rho_{0}^{f}}{\rho_{0}^{f}} e_{j}\right) \\
\varepsilon R_{d} \frac{\partial C}{\partial t}+q_{i}^{f} \frac{\partial C}{\partial x_{i}}-\frac{\partial}{\partial x_{i}}\left(D_{i j} \frac{\partial C}{\partial x_{j}}\right) \\
+\left(\epsilon R \vartheta+Q_{p}\right) C=Q_{C}
\end{array}\right.
$$

with the constitutive equations

$$
\begin{aligned}
& \rho^{f}=\rho_{0}^{f}\left[1+\frac{\bar{a}}{\left(C_{s}-C_{0}\right)}\left(C-C_{0}\right)\right], \\
& \bar{a}=\frac{\left[\rho^{f}\left(C_{s}\right)-\rho_{0}^{f}\right]}{\rho_{0}^{f}},
\end{aligned}
$$

$$
\begin{aligned}
& h=\frac{p^{f}}{\rho_{0}^{f} g}+x_{i} \\
& K_{i j}=\frac{k_{i j} \rho_{0}^{f} g}{\mu_{0}^{f}} \\
& f_{\mu}=\frac{\mu_{0}^{f}}{\mu^{f}(C, T)}= \\
& \frac{1+1.85 \omega_{\left(C=C_{0}\right)}-4.1 \omega_{\left(C=C_{0}\right)}^{2}+44.5 \omega_{\left(C=C_{0}\right)}^{3}}{1+1.85 \omega-4.1 \omega^{2}+44.5 \omega^{3}} \\
& \times \frac{1+0.7063 \varsigma-0.04832 \varsigma^{3}}{1+0.7063 \varsigma_{\left(T=T_{0}\right)}-0.04832 \varsigma_{\left(T=T_{0}\right)}^{3}} \\
& \varsigma=\frac{(T-150)}{100}, \quad \omega=\frac{C}{\rho^{f}},
\end{aligned}
$$$$
D_{i j}=\left(\varepsilon D_{d}+\beta_{T} V_{q}^{f}\right) \delta_{i j}+\left(\beta_{L}-\beta_{T}\right) \frac{q_{i}^{f} q_{j}^{f}}{V_{q}^{f}}
$$$$
R=1+\frac{(1-\varepsilon)}{\varepsilon} \chi(C)
$$ 


$$
R_{d}=1+\frac{(1-\varepsilon)}{\varepsilon} \frac{[\chi(C) \cdot C]}{\partial C},
$$

which are to be solved for the three primary variables (a hydraulic head $h$, the Darcy velocity vector of fluid $q_{i}^{f}$, the concentration of chemical component or activity concentration of the radionuclide $C$ ).

The main governing parameters are the following: $\rho^{f}, \rho_{0}^{f}$ is the fluid and reference fluid density, respectively; $\rho^{\mathrm{s}}$ the solid density; $S_{0}$ the specific storage coefficient (compressibility); $K_{i j}$ a tensor of the hydraulic conductivity; $e_{j}$ the gravitational unit vector; $f_{\mu}$ the constitutive viscosity relation function; $Q_{E B}$ the term of extended Boussinesq approximation; $R$ the specific retardation factor; $R_{d}$ the derivative term of retardation; $D_{i j}$ the tensor of the hydrodynamic dispersion; $\delta_{i j}$ the Kronecker tensor; $v$ the decay rate ( $\lambda$ is the most conventional designation for the radioactive decay rate); $\varepsilon$ is porosity (effective); $Q_{x}$ the source/ sink function of fluid $(x=\rho)$ and contaminant mass $(x=C) ; \bar{a}$ the fluid density difference ratio; $\bar{\beta}$ the fluid expansion coefficient; $C_{0}, T_{0}$ are reference values for concentration and temperature, respectively; $C_{s}$ is the maximum concentration; $p^{f}$ the fluid pressure; $g$ gravitational acceleration; $k_{i j}$ the tensor of permeability; $\mu^{f}, \mu_{0}^{f}$ dynamic viscosity and its reference value of fluid, respectively; $\zeta$ normalized temperature; $\omega$ the mass fraction; $D_{d}$ the molecular diffusion coefficient of fluid; $V_{q}^{f}=\sqrt{q_{i}^{f} q_{j}^{f}}$ the absolute Darcy fluid flux; $\beta_{L}, \beta_{T}$ longitudinal and transverse dispersivity of chemical species, respectively; $\chi(C)$ is the concentration-dependent adsorption function.

The relationships of retardation $R$ and $R_{d}$ can be summarized for Henry isotherm adsorption law as follows [4]:

$$
R=\varepsilon(1-\varepsilon) K, \quad R_{d}=\varepsilon+(1-\varepsilon) K,
$$

where $K$ is the Henry sorption coefficient.

The Henry sorption coefficient (used in the computer code) of the radionuclides is calculated as

$$
K=K_{\mathrm{d}} \rho^{\mathrm{s}},
$$

where $K_{\mathrm{d}}$ is the solid / liquid distribution coefficient for a particular radionuclide, $\mathrm{m}^{3} / \mathrm{kg}$, and $\rho^{\mathrm{s}}$ is the density of solid, $\mathrm{kg} / \mathrm{m}^{3}$.

The groundwater flow in all aquifers in a numerical model is attributed to 9 layers (10 slices) and is represented by the 3D finite-element grid of mesh elements (Figs. 1,2). The created layers are adjusted to geometry of lithological bodies. Based on schematization of

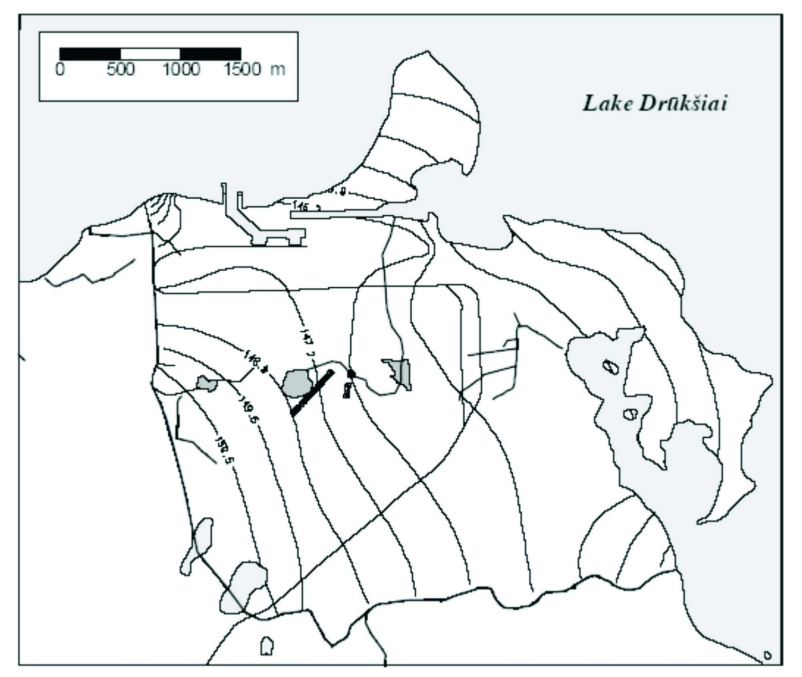

Fig. 4. Simulated hydraulic head (m a.s.1.) of the 7th layer representing semiconfined aquifer after 7165 years.

hydrogeological conditions, a rather complicated numerical model but conservative in terms of groundwater flow formulation was developed (Table 1).

The recharge rate from infiltration through the repository was assumed to be as follows: $0.41 \cdot 10^{-4} \mathrm{~m} /$ day for 0-100 years, $0.47 \cdot 10^{-4} \mathrm{~m} /$ day for $100-200$ years, $0.53 \cdot 10^{-4} \mathrm{~m} /$ day for $200-300$ years, and $0.57 \cdot 10^{-4}$ $\mathrm{m} /$ day for $>300$ years.

The geometrical discretization of the model domain and a set of parameter values representing boundary conditions of the groundwater flow and boundary conditions of mass transport after the model calibration are presented in Figs. 1,2 and Tables 2,3. The set of material characterizing parameters in modelled layers is shown in Table 4.

The main parameters (hydraulic conductivity, porosity, density, etc.) were chosen based on laboratory estimates and pumping tests. Other parameters (dispersivity, $K_{\mathrm{d}}$ or the Henry sorption coefficient, etc.) were selected from relevant lists and data bases $[5,6]$. The model domain for Stabatiške site was divided into separate polygons for variable input of hydrogeological parameters depending on lithology, topography, etc. Calibration of model parameters by recovering appropriate water budget and observed hydraulic head distribution at the site has been performed (Fig. 4). Once calibrated, the model was used to predict radionuclide transport within groundwater and the potential effect on the environment.

\section{Results and discussion}

The radionuclide release to aquatic pathway after closure of the repository and consequent contaminant 
Table 4. Parameters selected for different deposits of Stabatiškė site model domain.

\begin{tabular}{|c|c|c|c|c|c|c|c|c|}
\hline \multirow{2}{*}{ Layer } & \multirow{2}{*}{$\begin{array}{l}\text { Material description } \\
\quad \text { (prevailing) }\end{array}$} & \multirow{2}{*}{$\begin{array}{c}\text { Thickness, } \\
\text { m }\end{array}$} & \multirow{2}{*}{$\begin{array}{c}\text { Polygon } \\
\text { No. }\end{array}$} & \multirow{2}{*}{$\begin{array}{c}\text { Hydraulic } \\
\text { conductivity, } \\
10^{-4} \mathrm{~m} / \mathrm{s}\end{array}$} & \multirow{2}{*}{ Porosity } & \multirow{2}{*}{$\begin{array}{l}\text { Density, } \\
\mathrm{kg} / \mathrm{m}^{3}\end{array}$} & \multicolumn{2}{|c|}{ Henry sorption } \\
\hline & & & & & & & ${ }^{14} \mathrm{C}$ & ${ }^{129} \mathrm{I}$ \\
\hline \multirow[t]{5}{*}{1} & Peat & 1.0 & $\begin{array}{c}1,3,5-6,8, \\
13-14,17-18, \\
29,33,35-37\end{array}$ & 0.8 & 0.3 & 350 & 35 & 63 \\
\hline & Mixed grain sand & & $2,7,15$ & 4.2 & 0.26 & 2000 & 10 & 2 \\
\hline & Clay & & $4,27-28$ & $4.3 \mathrm{E}-4$ & 0.2 & 2300 & 2.3 & 2.3 \\
\hline & Till deposits (loam) & & & $2.0 \mathrm{E}-4$ & 0.07 & 2300 & 2.3 & 2.3 \\
\hline & Fine-grained sand & & $11,16,22-23,34$ & 0.6 & 0.26 & 2000 & 10 & 2 \\
\hline \multirow[t]{5}{*}{2} & Peat & 1.6 & $17-18,33,35-36$ & 0.8 & 0.3 & 350 & 35 & 63 \\
\hline & Mixed grain sand & & $2,7,15$ & 4.2 & 0.26 & 2000 & 10 & 2 \\
\hline & Fine-grained sand & & $11,16,22,34$ & 0.6 & 0.26 & 2000 & 10 & 2 \\
\hline & Clay & & $27-28$ & $4.3 \mathrm{E}-4$ & 0.2 & 2300 & 2.3 & 2.3 \\
\hline & Till deposits (loam) & & & $4.0 \mathrm{E}-5$ & 0.12 & 2300 & 2.3 & 2.3 \\
\hline \multirow[t]{8}{*}{3} & Peat & 6.5 & 36 & 0.8 & 0.3 & 350 & 35 & 63 \\
\hline & Mixed grain sand & & 2 & 4.2 & 0.26 & 2000 & 10 & 2 \\
\hline & Fine-grained sand & & 22 & 0.6 & 0.26 & 2000 & 10 & 2 \\
\hline & Till deposits (loam) & & & $4.0 \mathrm{E}-5$ & 0.07 & 2300 & 2.3 & 2.3 \\
\hline & Radioactive waste & & $38-39$ & $1.0 \mathrm{E}-5-$ & 0.25 & 2000 & $4000-$ & $4000-$ \\
\hline & (concrete matrix) & & & $<100$ years, & & & $<100$ years, & $<100$ years, \\
\hline & & & & $1.0 \mathrm{E}-4-$ & & & $2.3-$ & $2.3-$ \\
\hline & & & & $>100$ years & & & $>100$ years & $>100$ years \\
\hline \multirow[t]{6}{*}{4} & Mixed grain sand & 0.6 & 2 & 4.2 & 0.26 & 2000 & 10 & 2 \\
\hline & Till deposits (loam) & & & $4.0 \mathrm{E}-5$ & 0.07 & 2300 & 2.3 & 2.3 \\
\hline & Concrete & & $40-41$ & $1.0 \mathrm{E}-5-$ & 0.15 & 2300 & $460-$ & $7-$ \\
\hline & & & & $<100$ years, & & & $<100$ years, & $<100$ years, \\
\hline & & & & $1.0 \mathrm{E}-4-$ & & & $2.3-$ & $2.3-$ \\
\hline & & & & $>100$ years & & & $>100$ years & $>100$ years \\
\hline \multirow[t]{2}{*}{5} & Till deposits (loam) & 1.0 & & $4.0 \mathrm{E}-5$ & 0.07 & 2300 & 2.3 & 2.3 \\
\hline & $\begin{array}{l}\text { Sand and gravel } \\
\text { composite }\end{array}$ & & $40-41$ & $5.0 \mathrm{E}-3$ & 0.4 & 2000 & 10 & 2 \\
\hline 6 & Glacial loam & $3-8$ & & $4.0 \mathrm{E}-5$ & 0.07 & 2300 & 2.3 & 2.3 \\
\hline \multirow[t]{4}{*}{7} & Fine-grained sand & $5-17$ & 1 & 0.6 & 0.3 & 2100 & 10.5 & 2.1 \\
\hline & Mixed grain sand & & 7 & 1.9 & 0.3 & 2100 & 10.5 & 2.1 \\
\hline & Gravel & & 6 & 3.2 & 0.3 & 2100 & 10.5 & 2.1 \\
\hline & Fine-grained sand & & 4 & 0.8 & 0.3 & 2100 & 10.2 & 2.1 \\
\hline \multirow[t]{4}{*}{8} & Fine-grained sand & $6-10$ & 1 & 0.7 & 0.3 & 2100 & 10.5 & 2.1 \\
\hline & Mixed grain sand & & 7 & 1.3 & 0.3 & 2100 & 10.5 & 2.1 \\
\hline & Coarse-grained sand & & 6 & 2.4 & 0.3 & 2100 & 10.5 & 2.1 \\
\hline & Fine-grained sand & & 4 & 0.5 & 0.3 & 2100 & 10.5 & 2.1 \\
\hline 9 & Till deposits (loam) & $4-15$ & & $4.0 \mathrm{E}-5$ & 0.05 & 2300 & 2.3 & 2.3 \\
\hline
\end{tabular}

Dispersivity: longitudinal $5 \mathrm{~m}$, transverse $1 \mathrm{~m}$. Distribution coefficient $\left(K_{\mathrm{d}}\right):{ }^{14} \mathrm{C} 0.001 \mathrm{~m}^{3} / \mathrm{kg}$ (for clayey deposits), $0.005 \mathrm{~m}^{3} / \mathrm{kg}$ (for sandy deposits), $0.1 \mathrm{~m}^{3} / \mathrm{kg}$ (for peat), $2 \mathrm{~m}^{3} / \mathrm{kg}$ (for radioactive waste);

${ }^{129} \mathrm{I} 0.001 \mathrm{~m}^{3} / \mathrm{kg}$ (for clayey and sandy deposits), $0.18 \mathrm{~m}^{3} / \mathrm{kg}$ (for peat), $0.01 \mathrm{~m}^{3} / \mathrm{kg}$ (for radioactive waste);

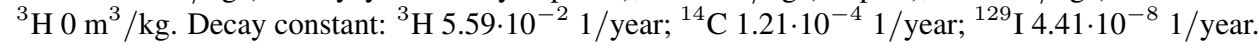




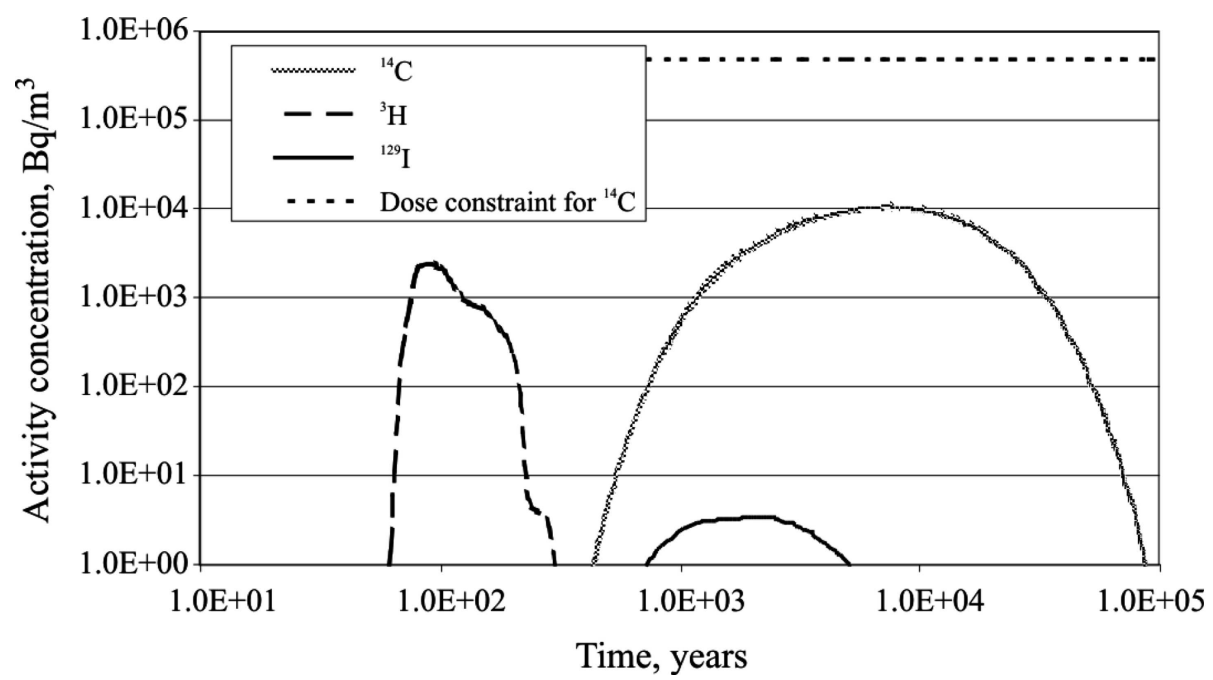

Fig. 5. Simulated time series of ${ }^{3} \mathrm{H},{ }^{14} \mathrm{C}$, and ${ }^{129} \mathrm{I}$ activity concentration in groundwater $150 \mathrm{~m}$ away from the repository (the 7 th layer, $26 \mathrm{~m}$ depth).

plume transport have been assessed taking into account site-specific geological and hydrogeological conditions and based on a normal evolution scenario. This scenario described the expected evolution of the disposal system including natural degradation of engineered barriers in a long-term perspective. The parameters of the environment are assumed to remain unchanged throughout the repository evolution.

A computer code FEFLOW enables spatial and temporal analysis of modelling results in many ways. The simulated activity concentration of radionuclides $\left({ }^{3} \mathrm{H}\right.$, ${ }^{14} \mathrm{C}$, and ${ }^{129} \mathrm{I}$ ) in groundwater downstream from the repository is presented in Fig. 5.

Out of three radionuclides for which the assessment by FEFLOW code was performed, the highest peak activity concentration in groundwater is predicted for the radioisotope ${ }^{14} \mathrm{C}$. The highest activity concentration of ${ }^{14} \mathrm{C}$ (about $10000 \mathrm{~Bq} / \mathrm{m}^{3}$ ) is predicted in the water of the modelling well after 7165 years while its activity concentration in the shallow modelling well during approximately the same time is predicted to be lower (about $7400 \mathrm{~Bq} / \mathrm{m}^{3}$ ). It is caused by the radionuclide lower lateral migration rate in perched groundwater compared to semiconfined aquifer, which is characterized by higher hydraulic conductivity.

The ${ }^{3} \mathrm{H},{ }^{14} \mathrm{C}$, and ${ }^{129}$ I activity concentrations corresponding to the dose constraint of $0.2 \mathrm{mSv} /$ year for potable water pathway are $1.5 \cdot 10^{7}, 4.7 \cdot 10^{5}$, and $2.5 \cdot 10^{3} \mathrm{~Bq} / \mathrm{m}^{3}$, respectively. These values are evidently much higher compared to the predicted peak activity concentrations of respective radionuclides in groundwater. Therefore, more sensible illustration of contamination level is comparison of the model prediction with the contemporary activity levels of globally distributed radionuclides. Such levels of ${ }^{3} \mathrm{H},{ }^{14} \mathrm{C}$, and ${ }^{129}$ I activity concentrations in the aquatic environment are 1000,20 , and $0.001 \mathrm{~Bq} / \mathrm{m}^{3}$, respectively. The activity concentration of ${ }^{14} \mathrm{C}$ at the modelling point will exceed the global level. However, the inventory value of this radionuclide in the calculation was conservatively accepted to be by an order of magnitude higher than it was determined during characterization of the first packages of the cemented waste (INPP Decommissioning Unit communication). The activity concentration of ${ }^{3} \mathrm{H}$ and ${ }^{129} \mathrm{I}$ in the inventory was also accepted to be by an order of magnitude higher. The area distribution of the ${ }^{14} \mathrm{C}$ activity concentration in groundwater of semiconfined aquifer for the moment of the maximum spreading (7165 years after the repository closure) is presented in Fig. 6.

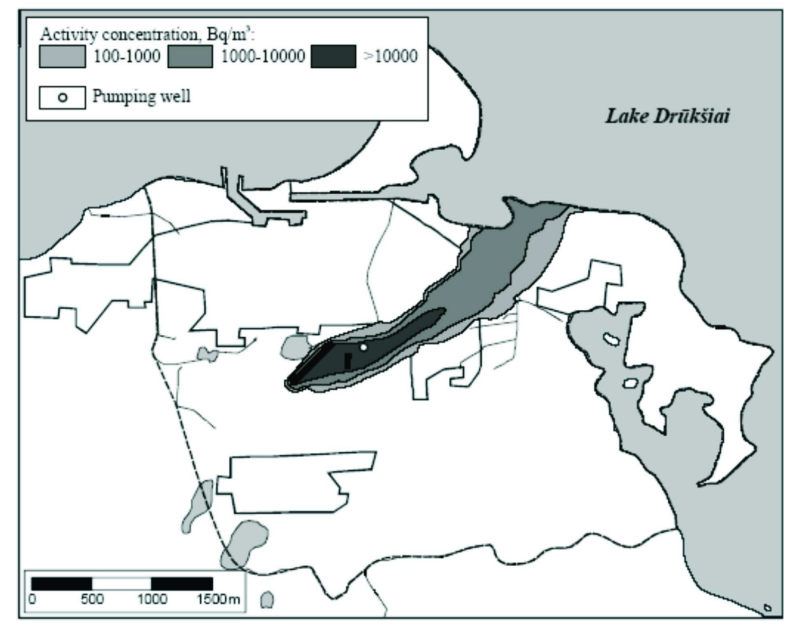

Fig. 6. Predicted contamination plume of ${ }^{14} \mathrm{C}$ in semiconfined aquifer at the moment of peak activity ( 7165 years after the repository closure). 
The predicted maximum contamination plume of the radionuclide ${ }^{14} \mathrm{C}$ (activity concentration is about $10000 \mathrm{~Bq} / \mathrm{m}^{3}$ ) is spread at the distance of some kilometres from the repository and with the base flow it reaches Lake Drūkšiai. However, the base flow near the beach of the lake is a very small quantity in comparison with the water volume of the lake, so the contamination plume of ${ }^{14} \mathrm{C}$ is attenuated. The distribution area of activity concentration of other radionuclides in groundwater at the moment of their peak is much smaller in comparison with that of the activity concentration of ${ }^{14} \mathrm{C}$.

The uncertainties contributing to the spreading of radionuclides in the environment and to the evaluation of effective doses can be grouped into these main categories [7]: (i) uncertainties of scenarios - uncertainties related to the predicted inaccuracy of the evolution of the disposal system; (ii) uncertainties of modelling related to the simplifications of natural and engineering realities which are used in the conceptual models and with differences in the applied computer codes and mathematical models used in modelling; (iii) uncertainties of parameters depending on the suitable application of parameters for the environment used in the calculations.

It was impossible to evaluate the uncertainties of predicted values by using the Monte Carlo simulation method, therefore only variability of some parameters and its effects on minimal and maximal model predictions were analysed in this work.

Dispersivity of permeable sediments forming aquifers and aquitards ranges within four orders of magnitude - from 0.01 to $100 \mathrm{~m} \mathrm{[6]}$. The dispersivity at the site was not determined in this work. For certain materials dispersivity values (minimal, maximal, median) were assumed from generic lists [6]. The most variable hydraulic property of porous sediments is hydraulic conductivity, which of natural porous materials ranges within twelve orders of magnitude - from $1 \mathrm{~m} / \mathrm{s}$ for coarse gravel to $10^{-12} \mathrm{~m} / \mathrm{s}$ for fine clay $[8,9]$. For rather limited hydraulic media as that typical of Stabatiške site, the range of hydraulic conductivity is smaller - from $3.5 \cdot 10^{-9} \mathrm{~m} / \mathrm{s}$ (the lowest value for aquitard) to $3.1 \cdot 10^{-4} \mathrm{~m} / \mathrm{s}$ (the highest value for aquifer), but nevertheless it embraces five orders of magnitude. For particular material this range is even smaller. For instance, the range of hydraulic conductivity for low permeable till deposits (10 estimations in falling head cells) is: the minimal value $3.5 \cdot 10^{-9} \mathrm{~m} / \mathrm{s}$, the maximal value $1.5 \cdot 10^{-7} \mathrm{~m} / \mathrm{s}$, and median $2.7 \cdot 10^{-8} \mathrm{~m} / \mathrm{s}$. The range of hydraulic conductivity for assessed aquifer (6 estimations from pumping tests, 6 computations from particle size distribution analysis; data provided by JSC "GROTA" is:

Table 5. Parameters selected for variability analysis of radionuclide transport model for Stabatiške site.

\begin{tabular}{|c|c|c|c|c|c|c|c|c|c|c|}
\hline \multirow{2}{*}{$\begin{array}{l}\text { Material description } \\
\text { (prevailing) }\end{array}$} & \multicolumn{2}{|c|}{$\begin{array}{c}\text { Minimal dispersivity*, } \\
\mathrm{m}\end{array}$} & \multicolumn{3}{|c|}{$\begin{array}{l}\text { Hydraulic conductivity, } \\
\qquad 10^{-4} \mathrm{~m} / \mathrm{s}\end{array}$} & \multicolumn{3}{|c|}{ Porosity } & \multicolumn{2}{|c|}{$\begin{array}{l}\text { Henry sorption } \\
{ }^{14} \mathrm{C}\end{array}$} \\
\hline & long. & transv. & Normal & Min & Max & Normal & Min & $\operatorname{Max}$ & Normal & Min \\
\hline Peat & 0.01 & 0.001 & 0.8 & 0.08 & 8.0 & 0.30 & 0.16 & 0.5 & 35 & 2.3 \\
\hline Mixed grain sand & 0.1 & 0.01 & $\begin{array}{c}1.9 \\
1.3 \\
4.2^{* *}\end{array}$ & $\begin{array}{l}0.19 ; \\
0.13 ; \\
0.42^{* *}\end{array}$ & $\begin{array}{l}18.9 \\
13.1 \\
42.1^{* *}\end{array}$ & $\begin{array}{c}0.26 \\
0.30^{* *}\end{array}$ & 0.16 & 0.5 & $\begin{array}{c}10.0 \\
10.5- \\
\text { aquifer** }^{* *}\end{array}$ & 6.3 \\
\hline Clay & 0.01 & 0.001 & $4.3 \mathrm{E}-4$ & $4.3 \mathrm{E}-5$ & $4.3 \mathrm{E}-3$ & 0.20 & 0.01 & 0.5 & 2.3 & 2.3 \\
\hline Glacial loam & 0.01 & 0.001 & $\begin{array}{l}4.0 \mathrm{E}-5 \\
2.0 \mathrm{E}-4^{* *}\end{array}$ & $\begin{array}{l}4.0 \mathrm{E}-6 \\
2.0 \mathrm{E}-5^{* *}\end{array}$ & $\begin{array}{l}4.0 \mathrm{E}-4 \\
2.0 \mathrm{E}-3^{* *}\end{array}$ & $\begin{array}{c}0.07 \\
0.05^{* *}\end{array}$ & 0.02 & 0.2 & 2.3 & 2.3 \\
\hline Fine-grained sand & 0.1 & 0.01 & $\begin{array}{c}0.6 ; 0.8 \\
0.7 ; 0.5^{* *}\end{array}$ & $\begin{array}{c}0.06 ; 0.08 \\
0.07 ; 0.05^{* *}\end{array}$ & $\begin{array}{c}6.0 ; 8.0 \\
6.9 ; 5.3^{* *}\end{array}$ & $\begin{array}{c}0.26 \\
0.30^{* *}\end{array}$ & 0.01 & 0.5 & $\begin{array}{c}10.0 \\
10.5- \\
\text { aquifer** }^{* *}\end{array}$ & 6.3 \\
\hline $\begin{array}{l}\text { Radioactive waste } \\
\text { (concrete matrix) }\end{array}$ & 0.01 & 0.001 & $1.0 \mathrm{E}-5$ & $1.0 \mathrm{E}-6$ & $1.0 \mathrm{E}-4$ & 0.25 & 0.12 & 0.5 & 4000 & 2.3 \\
\hline Concrete & 0.01 & 0.001 & $1.0 \mathrm{E}-5$ & $1.0 \mathrm{E}-6$ & $1.0 \mathrm{E}-4$ & 0.15 & 0.07 & 0.3 & 460 & 2.3 \\
\hline $\begin{array}{l}\text { Sand and gravel } \\
\text { composite }\end{array}$ & 0.1 & 0.01 & $5.0 \mathrm{E}-3$ & $5.0 \mathrm{E}-4$ & $5.0 \mathrm{E}-2$ & 0.40 & 0.20 & 0.8 & 10.0 & 6.3 \\
\hline Gravel & 0.1 & 0.01 & 3.2 & 0.32 & 31.5 & 0.30 & 0.16 & 0.5 & 10.5 & 6.3 \\
\hline Coarse-grained sand & 0.1 & 0.01 & 2.4 & 0.24 & 23.7 & 0.30 & 0.16 & 0.5 & 10.5 & 6.3 \\
\hline
\end{tabular}

\footnotetext{
${ }^{*}$ for all materials normal longitudinal dispersivity is $5 \mathrm{~m}$, maximal $10 \mathrm{~m}$, and transverse dispersivities, normal and maximal, are $1 \mathrm{~m}$

** slightly different values assumed for different layers
} 


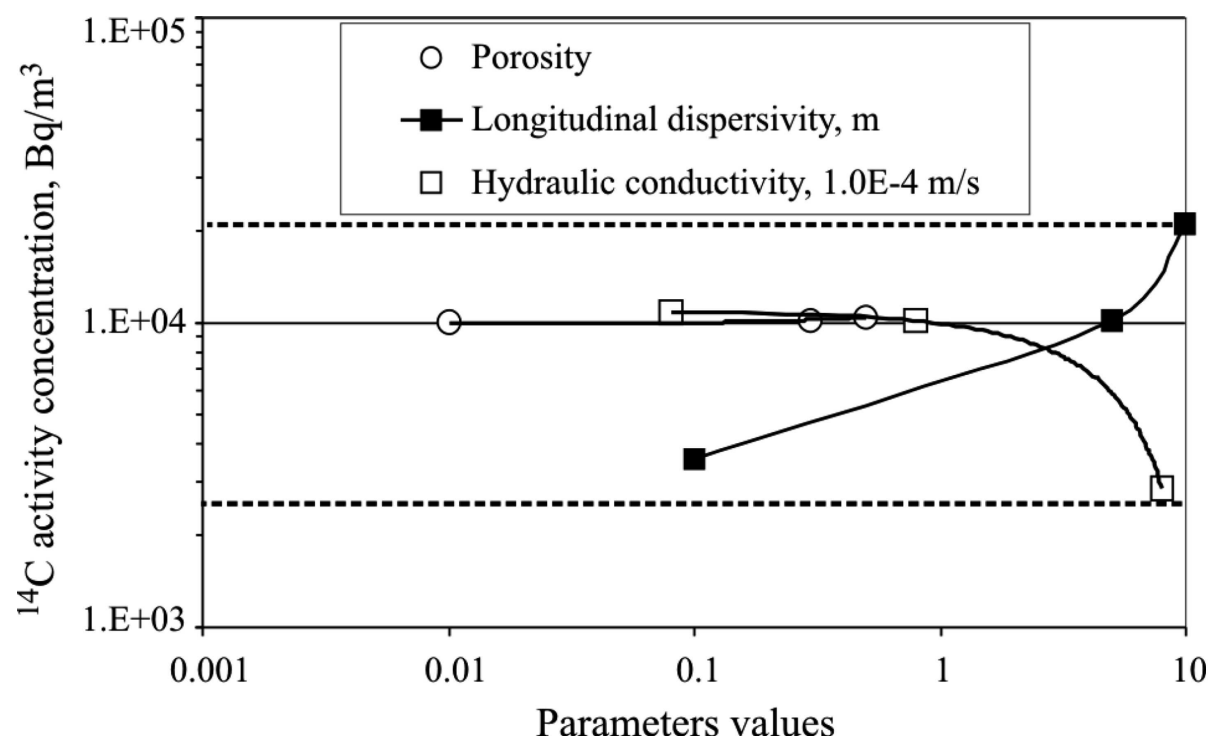

Fig. 7. Variability of ${ }^{14} \mathrm{C}$ peak activity concentration 8000 years after the repository closure versus porosity, dispersivity, and hydraulic conductivity. Lower bound of ${ }^{14} \mathrm{C}$ is $2800 \mathrm{~Bq} / \mathrm{m}^{3}$, upper bound $21000 \mathrm{~Bq} / \mathrm{m}^{3}$, mean value $10150 \mathrm{~Bq} / \mathrm{m}^{3}$.

the minimal value $5.3 \cdot 10^{-5} \mathrm{~m} / \mathrm{s}$, the maximal value $3.1 \cdot 10^{-4} \mathrm{~m} / \mathrm{s}$, and median $2.0 \cdot 10^{-4} \mathrm{~m} / \mathrm{s}$. Values of porosity and density along with other geotechnical characteristics were determined for different natural materials during investigations of Stabatiške site. There are several methods for the determination of the effective porosity. Differences between the total and effective porosity are small for gravel and sand. For such materials, effective porosity may be regarded as equal to the total porosity. For loam and clay material, differences between total and effective porosities are larger [10] and the effective porosity needs to be determined separately. The most reliable way of determining the effective porosity is by means of a tracer test. The tracer test in low permeable materials in our case was not done. The values of the effective porosity were derived from the values of the total porosity by applying the ratio of the total porosity/effective porosity equal to 7 [10]. Values of $K_{\mathrm{d}}$ for mobile radionuclides $\left({ }^{3} \mathrm{H},{ }^{14} \mathrm{C}\right.$, and $\left.{ }^{129} \mathrm{I}\right)$ for different natural and engineering materials were not determined at Stabatiške site. For tested materials, $K_{\mathrm{d}}$ values (minimal, maximal, median) were selected from generic lists tending to most conservative values close to zero $[6,7]$.

For the parameter variability analysis, runs of the model were made for three sets of dispersivity, hydraulic conductivity, porosity, and $K_{\mathrm{d}}$ values for ${ }^{3} \mathrm{H}$, ${ }^{14} \mathrm{C}$, and ${ }^{129} \mathrm{I}$ (Table 5). Among analysed radionuclides, ${ }^{14} \mathrm{C}$ showed the largest variability of results. Results of predicted activity concentration dependence on variability of single parameter, when values of other pa- rameters are fixed, are shown in Fig. 7 for ${ }^{14} \mathrm{C}$ for three parameters.

From the analysed parameters the result of assessment least of all depends on the effective porosity. Conservatively minimal $K_{\mathrm{d}}$ values are close to zero as radionuclides under consideration are mobile, so their retardation in the model is accepted to be very small. The variability of the final result due to this parameter is also not significant. The largest variability is determined due to the dispersivity (the ratio of upper and lower bounds for the peak activity of ${ }^{14} \mathrm{C} 8000$ years after the repository closure is 5.7) and to hydraulic conductivity (the ratio of upper and lower bound for the peak activity of ${ }^{14} \mathrm{C}$ is 3.8 ).

\section{Conclusions}

Calculations of the radionuclide spreading by the computer code FEFLOW 5.0 allow us to demonstrate the influence of the groundwater flow on the repository performance and identify governing parameters of the transfer of mobile radionuclides in the related hydrogeological system. The parametric variability of ${ }^{3} \mathrm{H},{ }^{14} \mathrm{C}$, and ${ }^{129} \mathrm{I}$ transfer using the groundwater flow model regarding the dispersivity, hydraulic conductivity, porosity, and radionuclide solid / liquid distribution coefficient $\left(K_{\mathrm{d}}\right)$ has been analysed. The results of ${ }^{14} \mathrm{C}$ simulation showed the largest variability depending on analysed parameters. The ratio of the upper and lower bounds at the peak activity concentration moment for this radionuclide due to the investigated parameters can reach 6 . The activity concentration of the most mobile 
radionuclides in aquifer will remain very low for a long time after the repository closure. The maximal annual effective dose to the hypothetic inhabitant contributed mainly by ${ }^{14} \mathrm{C}$ will not exceed $9 \cdot 10^{-3} \mathrm{mSv} / \mathrm{y}$ and will be lower than the dose constraint $(0.2 \mathrm{mSv} / \mathrm{y})$ if the low and intermediate level waste repository is established at Stabatiške site (INPP region, Lithuania).

\section{Acknowledgements}

This study was supported by the Lithuanian Radioactive Waste Management Agency (RATA) (Contract No. 3.3-6-13). The authors are grateful to Dr. Evaldas Maceika (Institute of Physics, Lithuania) for his valuable comments.

\section{References}

[1] Reference Design for a Near-Surface Repository for Low and Intermediate Level Short-Lived Radioactive Waste in Lithuania, LT NSR Final Project Report (SKB-SWECO International-Westinghouse Atom Joint Venture, 2002).

[2] S. Motiejunas, R. Pusch, J. Jonynas, J. Cyziene, and J. Satkunas, in: Book of Abstracts of 2 nd International Meeting. Clays in Natural and Engineered Barriers for Radioactive Waste Confinement, Tours (P/GSI/19, 2005) pp. 305-306.
[3] J. Mažeika and S. Motiejūnas, Perfomance of a near surface repository for LLW and MLW in Lithuania, in: Contributed Papers of International Conference on the Safety of Radioactive Waste Disposal, Tokyo, Japan, 3-7 October 2005 (IAEA, Vienna, 2005) pp. 213-216.

[4] H.J. Diersh, WASY Software FEFLOW. Finite Element Subsurface Flow and Transport Simulation System: Reference Manual (WASY Institute for Water Resources Planning and Systems Research Ltd., Berlin, Germany, 2002).

[5] Derivation of Activity Limits for the Disposal of Radioactive Waste in Near-Surface Disposal Facilities, IAEA-TECDOC-1380 (2003).

[6] D. Mallants, Basic Concepts of Water Flow, Solute Transport, and Heat Flow in Soils and Sediments, 2nd ed. (SCK•CEN, Belgium, 2006).

[7] Safety Assessment Methodologies for Near Surface Disposal Facilities. Results of a Co-ordinated Research Project. Vol. 1. Review and Enhancement of Safety Assessment Approaches and Tools (IAEA, Vienna, 2004).

[8] G. De Marsily, Quantitative Hydrogeology (Academic Press, San Diego, USA, 1986).

[9] C.W. Fetter, Applied Hydrogeology, 3rd ed. (PrenticeHall, New Jersey, USA, 1994).

[10] D. Mallants, G. Volckaert, and S. Labat, Parameter Values Used in the Performance Assessment of the Disposal of Low Level Radioactive Waste at the Nuclear Zone 153 Mol-Dessel. Vol. 2: Annexes to the Data Collection Forms for Engineered Barriers, Report R-3352 (SCK•CEN, Mol, Belgium, 2003).

\title{
MAŽO IR VIDUTINIO AKTYVUMO RADIOAKTYVIŲJU ATLIEKŲ PAVIRŠINIO KAPINYNO STABATIŠKĖ̇ AIKŠTELĖJE SAUGOS ANALIŻ்
}

\author{
V. Jakimavičiūtė-Maseliené ${ }^{a, b, c}, J$. Mažeika ${ }^{b}$, D. Baltrūnas ${ }^{a}$ \\ ${ }^{a}$ Fizikos institutas, Vilnius, Lietuva \\ ${ }^{\mathrm{b}}$ Geologijos ir geografijos institutas, Vilnius, Lietuva \\ ${ }^{\mathrm{c}}$ Vilniaus Gedimino technikos universitetas, Vilnius, Lietuva
}

\section{Santrauka}

Apie $100000 \mathrm{~m}^{3}$ mažo ir vidutinio aktyvumo radioaktyviųju atliekų, susidarančių Ignalinos AE eksploatacijos metu bei susidarysiančiu ją išmontuojant, turès būti palaidotos paviršiniame „kalvos“ tipo kapinyne. Vietovès parinkimo metu kaip viena iš geriausiu alternatyvų buvo pasirinkta Stabatiškès aikštelè (Ignalinos AE rajonas).

Paviršinio kapinyno Stabatiškès aikštelèje preliminariai saugos analizei buvo naudota kompiuterinè programa FEFLOW 5.0. Detaliau buvo modeliuoti trys radionuklidai $\left({ }^{3} \mathrm{H},{ }^{14} \mathrm{C},{ }^{129} \mathrm{I}\right)$, dèl blogu sorbcinių savybių iliustruojantys galimos didžiausios taršos mastus. Tričio bei ${ }^{129} \mathrm{I}$ tūriniai aktyvumai (atitinkamai iki $2500 \mathrm{~Bq} / \mathrm{m}^{3}$ po $92-95$ metu ir $3,4 \mathrm{~Bq} / \mathrm{m}^{3}$ po $1900-2000$ metų) vandeningame sluoksnyje $150 \mathrm{~m}$ atstumu nuo kapinyno nebus žymūs. Prognozuo- jamas didesnis ${ }^{14} \mathrm{C}$ tūrinis aktyvumas $\left(\sim 10000 \mathrm{~Bq} / \mathrm{m}^{3}\right.$ po 7100 7200 metų). Požeminiame vandenyje ${ }^{14} \mathrm{C}$ bei ${ }^{129}$ I sklaidos šleifas gali pasiekti Drūkšiu ežerą, tačiau tūriniai aktyvumai ežero vandenyje bus nedideli.

Stabatiškès aikštelèje modeliuota kai kurių parametrų (pasiskirstymo koeficiento, aplinkos dispersiškumo, filtracijos koeficiento bei poringumo) kaita, lemianti nuklidų sklaidos ịvertinimą. Didžiausią ịtaką skaičiavimo rezultatams turès aplinkos dispersiškumo pokyčiai, mažiau atsispindès pasiskirstymo bei filtracijos koeficientų kaita. Mažiausią îtaką ivertinimui turès poringumo parametro kaita.

Modeliavimo rezultatai rodo, jog svarbiausių radionuklidų tūriniai aktyvumai vandeningame sluoksnyje bus maži ilgą laiką po kapinyno uždarymo ir metiné efektinė dozė hipotetiniam gyventojui bus mažesnè už apribotają metinę dozę $(0,2 \mathrm{mSv} / \mathrm{m}$.). 